\title{
Protective Potential of Quercetin on Cd-Induced Hepatorenal Damage
}

\author{
Azza Sedky ${ }^{1}$, Fayza Mahboub $^{2}$, Hany Elsawy ${ }^{3,4 *}$, Rania Eid ${ }^{5}$ \\ ${ }^{1}$ Zoology Department, Faculty of Science, Alexandria University, Alexandria, Egypt \\ ${ }^{2}$ Biology Department, Faculty of Applied Science, Umm-Al Qura University, King Saudi Arabia \\ ${ }^{3}$ Chemistry Department, Faculty of Science, Tanta University, Tanta, Egypt \\ ${ }^{4}$ Chemistry Department,College of Science, King Faisal University, \\ Al Ahsaa, P.B. Box 380, Hufof 31982, Saudi Arabia \\ ${ }^{5}$ Physiology Department, Faculty of Medicine, Aswan University
}

Received: 29 November 2016

Accepted: 13 February 2017

\begin{abstract}
Industrial and environmental pollution are sources of cadmium $(\mathrm{Cd})$ exposure that cause serious health hazards. In this work we investigated the protective effect of quercetin on Cd-induced hepatorenal damage in rats. Cd toxicity was confirmed by evaluating its level in serum and tissues. Liver function enzymes, bilirubin, albumin, creatinine, uric acid, and urea were assessed in serum. However, lipid peroxidation and the activity of the antioxidant enzymes were examined in tissues. In addition, liver and kidney were studied histologically. Our results showed that the concentration of Cd was higher in tissues of Cd-treated rats while in the $\mathrm{Cd}$ and quercetin co-treated group, the $\mathrm{Cd}$ concentration was significantly reduced. Co-administration of $\mathrm{Cd}$ with quercetin improved the liver function as evident by the reduced levels of ALP, ALT, AST, bilirubin, and the increase in concentration of total protein and albumin. Also, kidney restored its normal function as well as lipid peroxidation, and the antioxidant enzymes partially restored their normal values. In addition, the protective effect of quercetin on the hepatorenal damage induced by $\mathrm{Cd}$ was confirmed histologically. In conclusion, quercetin treatment may provide protection against the damages induced by Cd exposure.
\end{abstract}

Keywords: Cd toxicity, hepatorenal damage, quercetin

\section{Introduction}

Cadmium, a non-essential transition heavy metal, is commonly regarded as a pollutant of worldwide concern [1]. It is present in the soil, water, air, food, and in cigarette smoke [2]. In people occupationally exposed to $\mathrm{Cd}$, the

*e-mail: hmostafa@kfu.edu.sa

main route of entry into the body is $\mathrm{Cd}$ inhalation, but also the intake of $\mathrm{Cd}$ via digestive tract and skin contributes to total exposure [3]. It is a toxicant that has a long biological half-life (15-20 years) and accumulates over time within the blood, kidneys, and liver [4]. Cd causes poisoning in various tissues of humans and animals [2]. Evidence suggests that $\mathrm{Cd}$ exposure enhances intracellular reactive oxygen species production and lipid peroxidation, which may led to tissue damage [5]. Liver and kidneys are important organs of metabolism, detoxification, storage, 
and excretion of xenobiotics and their metabolites, and are especially vulnerable to damage [6]. The greatest body accumulation of $\mathrm{Cd}$ occurs in the liver and kidney [7]. Cd is toxic to several tissues, most notably causing hepatotoxicity as well as nephrotoxicity upon exposure [8]. It can induce biochemical changes in liver and kidney. In liver it can decrease alanine transaminase (ALT), aspartate transaminase (AST), and alkaline phosphatase (ALP) activities and bilirubin levels, and decrease albumin and total protein [9]. In kidney it causes an increase in urea, uric acid, and creatinine [10]. Histologically, treatment with $\mathrm{Cd}$ causes severe damage, including fatty changes, necrosis, pyknotic nuclei, karayolysis, and proliferation of kupffer cells [11]. In kidney it causes shrinkage or regeneration of cells of the renal tubules, pyknoric nuclei, and haemorage [12]. It also causes oxidative stress related renal dysfunction [13].

Quercetin is a natural flavonoid present in high concentrations in fruits and vegetables [13]. Flavonoids can prevent oxidative damage as a result of their ability to scavenge reactive oxygen species, such as hydroxyl radical and superoxide anion, [14] and metal chelating [15]. The powerful antioxidant activity of flavonoids suggests that these compounds could play a protective role in oxidative stress-mediated diseases [16]. The purpose of this study was to determine the protective potential of quercetin on Cd-induced hepatic and renal damage.

\section{Materials and Methods}

\section{Animals}

Twenty adult male rats (Rattus norvejicus) weighing about 180-200 g (3 months old) were obtained from the Faculty of Agriculture, Alexandria University in Alexandria, Egypt. All animals were housed in plastic cages (five per cage) and kept under the same laboratory conditions of temperature $\left(25^{\circ} \mathrm{C}\right)$, humidity $(60 \%)$, and lighting (12 h light/12 h dark) for one week prior to the start of the experiment for acclimatization. The rats were given free access to food and water and fed with standard commercial rat chow.

\section{Chemicals}

Cd chloride and quercetin was purchased from Sigma chemicals (St. Louis, MO, USA). Reagent kits for assaying ALP, ALT, AST, total protein, urea, and creatinine were obtained from BioMed Diagnostics, Hannover, Germany. A reagent kit for assaying bilirubin was obtained from Diamond Diagnostics, Duesseldorf, Germany. Reagent kits for assaying uric acid and albumin were obtained from SPECTRUM, Cairo, Egypt.

\section{Experimental Design}

Animals were randomly divided into four groups of five animals each. Group I served as the control: rats were given daily normal saline $(0.9 \% \mathrm{NaCl})$ orally by gavage. Group II served as the $\mathrm{Cd}$ chloride-treated group: rats were given orally by gavage a daily dose of $\mathrm{Cd}$ chloride dissolved in normal saline at a concentration of $5 \mathrm{mg} / \mathrm{kg}$ body weight (b.w.) [13]. Group III served as the quercetintreated group: rats were given orally by gavage a daily dose of quercetin dissolved in normal saline at a concentration of $50 \mathrm{mg} / \mathrm{kg}$ b.w. [13]. Group IV served as the Cd chloride and quercetin co-treated group: rats were given orally by gavage a daily dose of $\mathrm{Cd}$ chloride at a concentration of $5 \mathrm{mg} / \mathrm{kg}$ b.w., followed by quercetin ( $50 \mathrm{mg} / \mathrm{kg} \mathrm{b.w.)}$. At the end of the four-week experimental period, the animals were sacrificed and blood samples and selected tissues were collected for analysis. The collected blood from each animal was centrifuged at 5,000 rpm for $10 \mathrm{~min}$; the separated sera were subjected to different blood analyses.

\section{Evaluation of Cd Level}

The Cd level was determined in blood, liver, and kidneys by the spectrophotometric method using o-diazoaminophenylarsonic acid azobenzene as a chromogenic reagent [17].

\section{Biochemical Measurments}

Liver function enzymes, bilirubin, albumin, creatinine, uric acid, and urea were determined in serum using their relevant commercial kits. Protein content was estimated according to the method of Lowery et al. (1951) [18] using bovine serum albumin as standard. Lipid peroxidation was performed as described by Buege and Aust (1978) [19]. The level of superoxide dismutase in tissues was measured by the nitro-blue tetrazolium decrease method of McCord and Fridovich (1969) [20]. Catalase activity was estimated spectrophotometrically as described by Aebi (1974) [21]. The activity of glutathione peroxidase was measured according to the method of Rotruck et al. (1973) [22].

\section{Histological Examination}

Specimens of liver and kidney were collected from all experimental animals and fixed in $10 \%$ neutral buffered formalin for 24 hours, rinsed with water, dehydrated in alcohols, cleared in xylene, and embedded in paraffin. Tissue blocks were cut into thin sections ( 5 microns) and routinely stained with Haematoxylin and Eosin (H\&E) stain (Bancroft and Gamble, 2002) [23] and examined by light microscopy.

\section{Statistical Analysis}

Results were presented as mean \pm standard error of the mean (SE) obtained from five animals. The SPSS program was used for the statistical analysis of data (one-way ANOVA) to compare the groups. In all cases, a difference was considered significant at $\mathrm{P} \leq 0.05$. 
Table 1. Effects of quercetin on cadmium levels in blood, liver, and kidney.

\begin{tabular}{|c|c|c|c|c|}
\hline & & \multicolumn{3}{|c|}{ Cadmium levels } \\
\hline & $\mathrm{N}$ & $\begin{array}{c}\text { Blood } \\
\mu \mathrm{g} / \mathrm{ml}\end{array}$ & $\begin{array}{c}\text { Liver } \\
\mu \mathrm{g} / \mathrm{gm} \text {. Tissue }\end{array}$ & $\begin{array}{c}\text { Kidney } \\
\mu \mathrm{g} / \mathrm{gm} . \text { Tissue }\end{array}$ \\
\hline Group I & 5 & $0.013^{\mathrm{c}} \pm 0.03$ & $0.02^{\mathrm{c}} \pm 0.0$ & $0.02^{\mathrm{c}} \pm 0.0$ \\
\hline Group II & 5 & $4.68^{\mathrm{a}} \pm 0.17$ & $5.02^{\mathrm{a}} \pm 0.12$ & $3.38^{\mathrm{a}} \pm 0.18$ \\
\hline Group III & 5 & $0.02^{\mathrm{c}} \pm 0.0$ & $0.02^{\mathrm{c}} \pm 0.0$ & $0.02^{\mathrm{c}} \pm 0.0$ \\
\hline Group IV & 5 & $1.40^{\mathrm{b}} \pm 0.19$ & $2.12^{\mathrm{b}} \pm 0.10$ & $0.76^{\mathrm{b}} \pm 0.06$ \\
\hline F (p) & & $284.750\left(<0.001^{*}\right)$ & $995.359\left(<0.001^{*}\right)$ & $279.381\left(<0.001^{*}\right)$ \\
\hline
\end{tabular}

Normally distributed data was expressed in mean \pm SE and was compared using F test (ANOVA) and was using Post Hoc Test (LSD) for comparison between groups. The different superscripts are significant

*Statistically significant at $\mathrm{P} \leq 0.05$

\section{Results and Discussion}

\section{Bioaccumulation of $\mathrm{Cd}$}

The concentration of $\mathrm{Cd}$ was significantly higher in blood, liver, and kidney of the Cd-treated group than the control group (Table 1). In the $\mathrm{Cd}$ and quercetin co-treated group, the $\mathrm{Cd}$ concentration was significantly reduced in the selected tissues in comparison to the Cd-treated group. This may be due to the metal chelating ability of quercetin [15]. The Cd levels of all groups increased in the order: liver $>$ blood $>$ kidney

\section{Biochemical Indicators of Liver Function}

The activities of ALT, ALP, and AST and the level of bilirubin were significantly higher in the Cd-treated group relative to that obtained from the control group (Table 2). However, the activities of ALP, ALT, and AST and the bilirubin level in $\mathrm{Cd}$ and the quercetin cotreated group were significantly lower compared to the Cd-treated group (Table 2). The exposure to $\mathrm{Cd}$ chloride significantly lowered the concentrations of total protein and albumin compared with concentration values obtained for the control group (Table 2). Similar observations were reported in many experimental investigations on animals exposed to $\mathrm{Cd}[11,24]$. The increased levels of studied enzymes in Cd-induced rats indicate an increased permeability and damage and/or necrosis of hepatocytes [9], which increase the release of these enzymes in the bloodstream [25]. In addition, the increase in bilirubin serum is a clear marker of hepatic dysfunction [13]. Moreover, the observed decrease in serum proteins may be due to the increased excretion of high molecular weight protein (Proteinurea) [26]. There is a significant increase in total protein and albumin concentrations in $\mathrm{Cd}$ chloride and the quercetin co-treated group compared with the Cd group. No significant changes in the studied serum parameters were observed among the quercetin-treated group when compared with the control group.

\section{Biochemical Indicators of Kidney Function}

The levels of urea and creatinine in the plasma of rats are measured as indicators for kidney function [27]. In this report, exposure to $\mathrm{Cd}$ chloride produced a significant increase in the values of uric acid, urea, and creatinine concentrations relative to the control group, confirming

Table 2. Effects of quercetin on some hepatic biochemical markers.

\begin{tabular}{|c|c|c|c|c|c|c|c|}
\hline & & \multicolumn{9}{|c|}{ Serum } \\
\hline & $\mathrm{N}$ & $\begin{array}{c}\text { ALT } \\
(\mathrm{U} / \mathrm{L})\end{array}$ & $\begin{array}{c}\text { AST } \\
(\mathrm{U} / \mathrm{L})\end{array}$ & $\begin{array}{c}\text { ALP } \\
(\mathrm{U} / \mathrm{L})\end{array}$ & $\begin{array}{c}\text { Bilirubin } \\
\mathrm{mg} / \mathrm{dl}\end{array}$ & $\begin{array}{c}\text { Total protein } \\
\mathrm{g} / \mathrm{dl}\end{array}$ & $\begin{array}{c}\text { Albumin } \\
\mathrm{g} / \mathrm{dl}\end{array}$ \\
\hline Group I & 5 & $51.0^{\mathrm{c}} \pm 2.10$ & $75.0^{\mathrm{c}} \pm 1.92$ & $54.60^{\mathrm{b}} \pm 1.60$ & $0.38^{\mathrm{c}} \pm 0.03$ & $7.30^{\mathrm{a}} \pm 0.13$ & $3.60^{\mathrm{a}} \pm 0.17$ \\
\hline Group II & 5 & $113.80^{\mathrm{a}} \pm 1.66$ & $154.60^{\mathrm{a}} \pm 0.98$ & $95.0^{\mathrm{a}} \pm 0.84$ & $0.76^{\mathrm{a}} \pm 0.01$ & $5.52^{\mathrm{c}} \pm 0.16$ & $1.78^{\mathrm{c}} \pm 0.09$ \\
\hline Group III & 5 & $45.80^{\mathrm{c}} \pm 2.03$ & $71.80^{\mathrm{c}} \pm 1.46$ & $53.40^{\mathrm{b}} \pm 1.86$ & $0.36^{\mathrm{c}} \pm 0.02$ & $7.38^{\mathrm{a}} \pm 0.12$ & $3.54^{\mathrm{a}} \pm 0.09$ \\
\hline Group IV & 5 & $72.80^{\mathrm{b}} \pm 1.85$ & $94.40^{\mathrm{b}} \pm 1.40$ & $48.60^{\mathrm{c}} \pm 1.50$ & $0.45^{\mathrm{b}} \pm 0.01$ & $6.72^{\mathrm{b}} \pm 0.17$ & $2.46^{\mathrm{b}} \pm 0.14$ \\
\hline \multicolumn{2}{|c|}{ F (p) } & $\begin{array}{c}259.966^{*} \\
\left(<0.001^{*}\right)\end{array}$ & $\begin{array}{c}674.026^{*} \\
\left(<0.001^{*}\right)\end{array}$ & $\begin{array}{c}246.331^{*} \\
\left(<0.001^{*}\right)\end{array}$ & $\begin{array}{c}80.753^{*} \\
\left(<0.001^{*}\right)\end{array}$ & $\begin{array}{c}35.442^{*} \\
\left(<0.001^{*}\right)\end{array}$ & $\begin{array}{c}50.552^{*} \\
\left(<0.001^{*}\right)\end{array}$ \\
\hline
\end{tabular}

Normally distributed data was expressed in mean \pm SE and was compared using F test (ANOVA) and was using Post Hoc Test (LSD) for comparison between groups. The different superscripts are significant

*Statistically significant at $\mathrm{P} \leq 0.05$ 
Table 3. Effect of quercetin on some renal biochemical markers.

\begin{tabular}{|c|c|c|c|c|}
\hline & & \multicolumn{3}{|c|}{ Serum } \\
\hline & $\mathrm{N}$ & $\begin{array}{l}\text { Urea } \\
\mathrm{mg} / \mathrm{dl}\end{array}$ & $\begin{array}{l}\text { Creatinine } \\
\mathrm{mg} / \mathrm{dl}\end{array}$ & $\begin{array}{l}\text { Uric acid } \\
\mathrm{mg} / \mathrm{dl}\end{array}$ \\
\hline Group I & 5 & $21.20^{c} \pm 0.86$ & $0.39^{b} \pm 0.01$ & $1.75^{\mathrm{c}} \pm 0.05$ \\
\hline Group II & 5 & $46.20^{\mathrm{a}} \pm 1.83$ & $0.69^{\mathrm{a}} \pm 0.03$ & $2.94^{\mathrm{a}} \pm 0.05$ \\
\hline Group III & 5 & $20.60^{c} \pm 1.21$ & $0.39^{b} \pm 0.01$ & $1.32^{\mathrm{b}} \pm 0.04$ \\
\hline Group IV & 5 & $35.40^{\mathrm{b}} \pm 1.29$ & $0.44^{b} \pm 0.02$ & $1.67^{\mathrm{c}} \pm 0.06$ \\
\hline \multicolumn{2}{|c|}{$\mathrm{F}(\mathrm{p})$} & $84.169^{*}\left(<0.001^{*}\right)$ & $55.752^{*}\left(<0.001^{*}\right)$ & $202.769^{*}\left(<0.001^{*}\right)$ \\
\hline
\end{tabular}

Normally distributed data was expressed in mean \pm SE and was compared using F test (ANOVA) and was using Post Hoc Test (LSD) for comparison between groups. The different superscripts are significant

*Statistically significant at $\mathrm{P} \leq 0.05$

a pronounced impairment in kidney function. Previous reports have shown that $\mathrm{Cd}$ induces an increase in these markers [10, 28-29]. Increased urea and creatinine levels may be attributed to the $\mathrm{Cd}$ bound to metallothionin in the liver and released into plasma, then filtered in the glomerular and taken by the proximal tubules of the kidney, thus damaging the proximal tubular cells of the kidney [30]. However, there was a significant decrease in uric acid, urea, and creatinine levels in $\mathrm{Cd}$ and the quercetin co-treated group compared with the Cd-treated group. No significant changes in creatinine, urea, and uric acid levels were observed within the quercetin-treated group when compared with the control group (Table 3 ).

\section{Lipid Peroxidation and Antioxidant Enzymes}

Exposure of rats to $\mathrm{Cd}$ chloride produced a significant increase in the value of malonaldehyde (MDA) levels and a decrease in the activities of CAT, SOD, and GP enzymes relative to the control group as shown in Table 4. However, there was a significant decrease in MDA levels and an increase in the activities of CAT, SOD, and
$\mathrm{GP}_{\mathrm{X}}$ enzymes in $\mathrm{Cd}$ and the quercetin co-treated group compared with the Cd-treated group. No significant changes in such tested parameters were observed among the quercetin-treated group when compared with the control group. Previous studies have strongly emphasized that quercetin is considered a surpass free-radical scavenging antioxidant [31] owing to its high number of hydroxyl groups and an ability to donate electrons or hydrogens, and scavenge hydroxyl groups, hydrogen peroxide, and superoxide anions [32]. The free radicals attack hepatic cells, leading to hepatic toxicity and dysfunction [33]. Also, Cd nephrotoxicity was reported to result from generating free radicals and thus inducing cell necrosis and apoptosis [34]. The molecular mechanism that may be responsible for the toxicity of $\mathrm{Cd}$ involves oxidative stress disturbing the antioxidant defense system [35]. Cd has been shown to stimulate the production of reactive oxygen species (ROS) due to an inhibitory effect on mitochondrial electron transport [36]. ROS may lead to cellular damage when the rate of its generation surpasses the rate of its decomposition by antioxidant defense systems, such as the enzymes catalase (CAT), superoxide

Table 4. Effect of quercetin on lipid peroxidation and antioxidant enzymes in liver and kidney.

\begin{tabular}{|c|c|c|c|c|c|c|c|c|c|}
\hline & & \multicolumn{9}{|c|}{ Tissue } \\
\hline & & \multicolumn{9}{|c|}{ Liver } & \multicolumn{3}{c|}{ Kidney } \\
\hline & $\mathrm{N}$ & MDA & SOD & $\mathrm{GP}_{\mathrm{x}}$ & CAT & MDA & SOD & GP $_{\mathrm{x}}$ & CAT \\
\hline Group I & 5 & $12.22^{\mathrm{c}} \pm 0.78$ & $69.60^{\mathrm{a}} \pm 1.08$ & $67.0^{\mathrm{a}} \pm 1.41$ & $47.0^{\mathrm{a}} \pm 1.38$ & $13.06^{\mathrm{c}} \pm 0.30$ & $53.20^{\mathrm{a}} \pm 1.93$ & $70.40^{\mathrm{a}} \pm 1.44$ & $47.60^{\mathrm{a}} \pm 1.78$ \\
\hline Group II & 5 & $53.0^{\mathrm{a}} \pm 1.14$ & $24.0^{\mathrm{c}} \pm 1.0$ & $33.40^{\mathrm{c}} \pm 1.29$ & $25.20^{\mathrm{c}} \pm 1.46$ & $50.80^{\mathrm{a}} \pm 1.36$ & $25.20^{\mathrm{c}} \pm 1.02$ & $35.20^{\mathrm{c}} \pm 1.74$ & $25.40^{\mathrm{c}} \pm 1.44$ \\
\hline Group III & 5 & $13.12^{\mathrm{c}} \pm 0.72$ & $68.0^{\mathrm{a}} \pm 1.05$ & $64.80^{\mathrm{a}} \pm 1.24$ & $45.60^{\mathrm{a}} \pm 1.63$ & $11.66^{\mathrm{c}} \pm 0.18$ & $55.0^{\mathrm{a}} \pm 1.41$ & $68.0^{\mathrm{a}} \pm 1.58$ & $46.40^{\mathrm{a}} \pm 1.29$ \\
\hline Group IV & 5 & $26.80^{\mathrm{b}} \pm 1.07$ & $43.20^{\mathrm{b}} \pm 1.43$ & $52.80^{\mathrm{b}} \pm 1.39$ & $35.80^{\mathrm{b}} \pm 1.46$ & $25.0^{\mathrm{b}} \pm 1.58$ & $38.20^{\mathrm{b}} \pm 1.83$ & $52.80^{\mathrm{b}} \pm 1.62$ & $35.0^{\mathrm{b}} \pm 1.22$ \\
\hline \multicolumn{2}{|c|}{ F (p) } & $\begin{array}{c}405.970^{*} \\
\left(<0.001^{*}\right)\end{array}$ & $\begin{array}{c}358.400^{*} \\
\left(<0.001^{*}\right)\end{array}$ & $\begin{array}{c}132.669^{*} \\
\left(<0.001^{*}\right)\end{array}$ & $\begin{array}{c}46.275^{*} \\
\left(<0.001^{*}\right)\end{array}$ & $\begin{array}{c}294.782^{*} \\
\left(<0.001^{*}\right)\end{array}$ & $\begin{array}{c}77.455^{*} \\
\left(<0.001^{*}\right)\end{array}$ & $\begin{array}{c}103.229^{*} \\
\left(<0.001^{*}\right)\end{array}$ & $\begin{array}{c}52.353^{*} \\
\left(<0.001^{*}\right)\end{array}$ \\
\hline
\end{tabular}

The values of MDA, SOD, GP $\mathrm{X}_{\mathrm{X}}$ and CAT are expressed as nmol/g tissue, $\mathrm{U} / \mathrm{mg}$ protein, $\mathrm{mU} / \mathrm{mg}$ protein and $\mathrm{U} / \mathrm{mg}$ protein, respectively. Normally distributed data was expressed in mean $\pm \mathrm{SE}$ and was compared using $\mathrm{F}$ test (ANOVA) and was using Post Hoc Test (LSD) for comparison between groups. The different superscripts are significant.

*Statistically significant at $\mathrm{P} \leq 0.05$ 


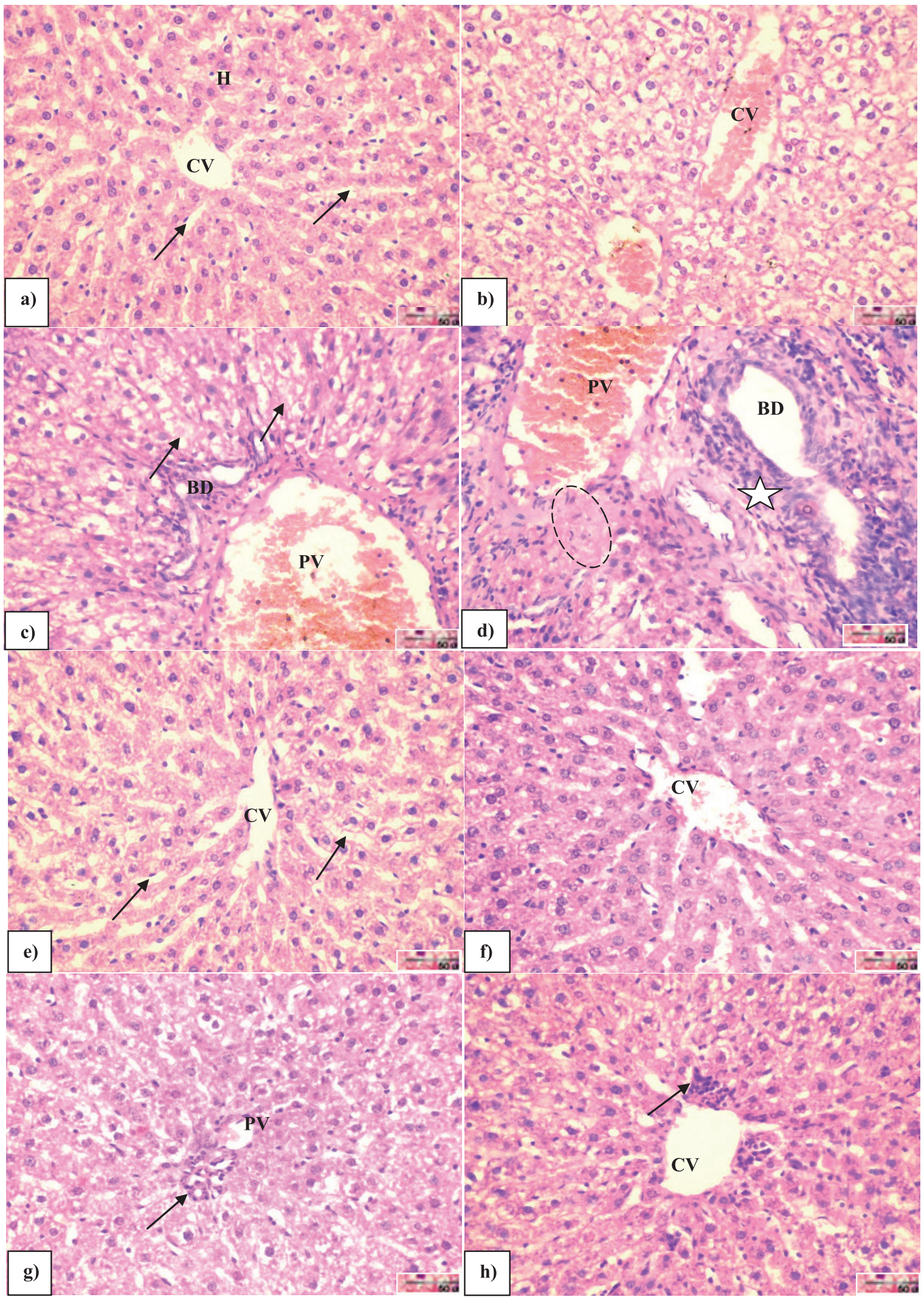

Fig. 1. Light micrographs of liver sections stained with H\&E. a) Hepatic tissue of the control group showing typical architecture, hepatocyte $(\mathrm{H})$ with normal nucleus, sinusoid (arrows) and central vein (CV); b-d) hepatic tissue of cadmium-treated group showing b) absence of hepatic architecture and congested dilated central vein $(\mathrm{CV}) ; \mathrm{c}$ ) vacuolated cytoplasm (arrows) and proliferation of bile ductule (BD); d) inflammatory cell infiltration (star), proliferation of bile ductule (BD), and fibrosis (circle); e) hepatic tissue of quercetin-treated group showing normal hepatocytes in-between blood sinusoid (S) and central vein (CV); f-h) hepatic tissue of cadmium and quercetin co-treated group showing f) great improvement of hepatocytes and slightly congested central vein (CV); g) proliferation of bile ductule (arrow) and portal vein (PV); and h) cellular infiltration (arrow) around central vein (CV). 


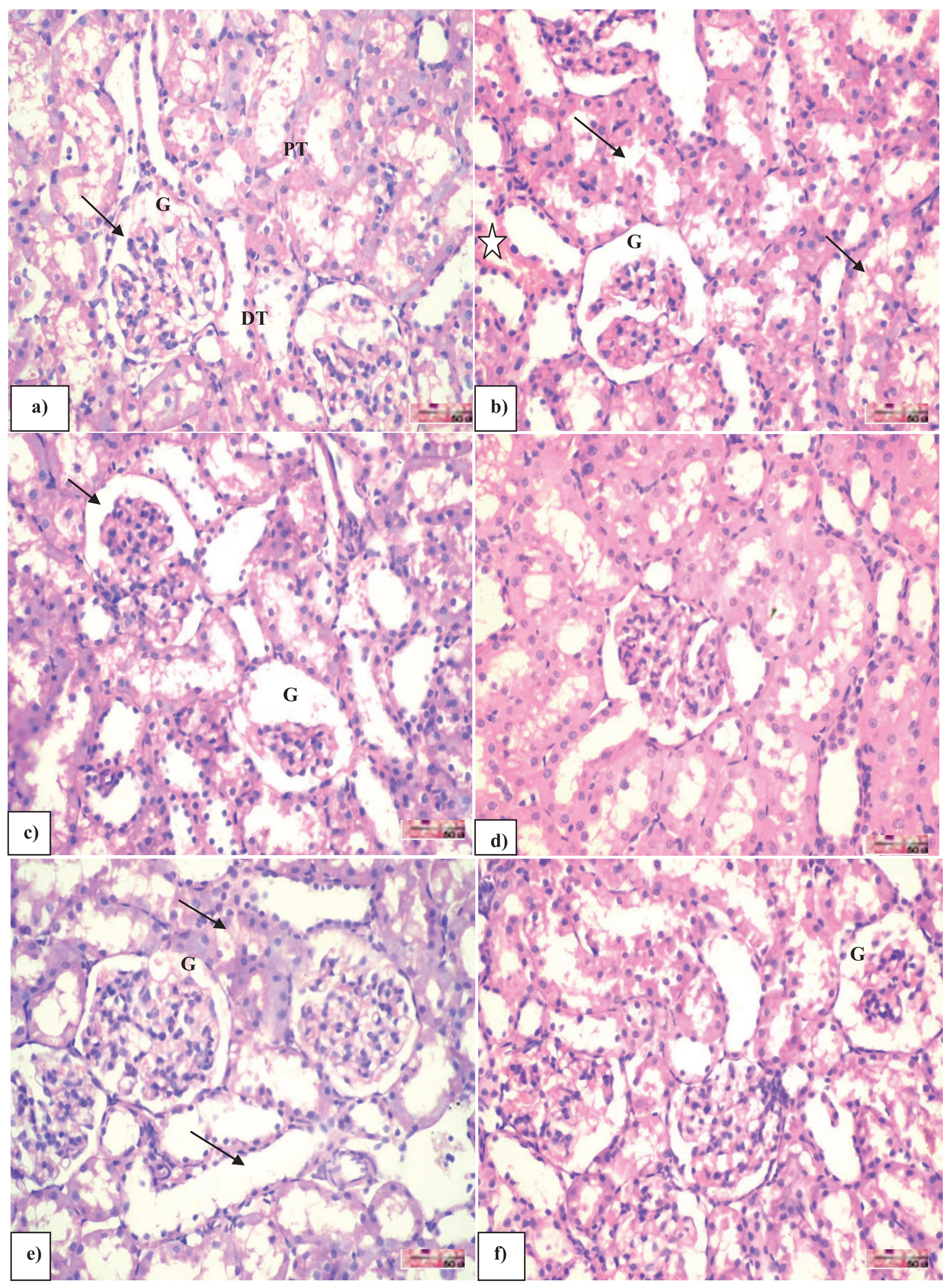

Fig. 2. Light micrographs of kidney sections stained with H\&E. a) Cortical tissue of the control group with normal glomerular tuft (G), urinary space (arrow), proximal tubule (PT), and distal tubule (DT); b, c) cortical tissue of cadmium-treated group showing b) interstitial blood congestion (arrow), renal corpuscle with focally segmented glomerulus (G), and disorganization of renal tubules (arrows); c) atrophied glomerulus $(\mathrm{G})$ with wide urinary space (arrow); d) cortical tissue of quercetin-treated group showing normal appearance; e, f) cortical tissue of cadmium and quercetin co-treated group showing (e) prominent recovery in both renal corpuscles $(\mathrm{G})$ and renal tubules (arrows); and f) still affected few renal corpuscles $(\mathrm{G})$. 
dismutase (SOD), and Glutathione peroxidase $\left(\mathrm{GP}_{X}\right)$ [37]. In the present study, the activities of SOD, CAT, and $\mathrm{GP}_{x}$ were decreased in the liver and kidney of Cd-treated rats. This comes in agreement with many reports $[11,38]$. SOD activity is strongly inhibited by $\mathrm{Cd}$, probably by interacting with metal moieties of SOD $(\mathrm{Cu}, \mathrm{Zn}$, or $\mathrm{Mn})$ and thus reducing activity. Alternatively, $\mathrm{Cd}$ may alter protein conformation by interacting with the enzyme and thereby altering its functional activity [39]. Cd also inhibits the activities of many enzymes by binding to their thiol groups or by inhibiting the protein synthesis [40]. Lipid peroxidation (LPO) is one of the main expressions of oxidative damage and is found to play an important role in the toxicity of Cd [41]. In this study, the lipid peroxidation levels were increased in liver and kidney of rats treated with $\mathrm{Cd}$. This agrees with the results [11, 42]. Cd has been reported to cause damage to lipids by generating LPO [11]. In contrast, quercetin treatment increased the activities of SOD, CAT, and GPx enzymes and decreased LPO in rats intoxicated with $\mathrm{Cd}$. Similar results were obtained by [43]. In this study, the ability of quercetin to increase the activities of SOD, CAT, and $\mathrm{GP}_{\mathrm{X}}$ may be due to the free radical scavenging action of quercetin, which may result from the presence of the 3-hydroxyl group in the C-ring and the 3', 4' dihydroxy group in the B-ring [44].

\section{Liver Histopathology}

Liver of the control group showed typical lobular architecture. The polygonal hepatic cells with central nuclei and uniform cytoplasm arranged in strands originated from the central vein. The well-organized blood sinusoid in-between the hepatic strands is connected to the central vein and contained Kupffer cells. Both central vein and sinusoids were clean (Fig. 1a).

In the $\mathrm{Cd}$ chloride-treated group, several pathological changes were observed in hepatic tissue. The hepatic architecture was lost where most hepatocytes appeared fused together to form eosinophilic syncytial masses with the absence of blood sinusoid lumens in most regions of Cd-treated rat liver. The hepatocytes appeared large with light and foamy cytoplasm filled with numerous vacuolelike spaces with heterochromatic nuclei (Figs 1b-c). The central blood vessels appeared dilated and congested (Fig. 1b). In some areas, mild perivascular fibrosis in the portal area were observed with portal vein congestion and proliferation of bile ductule (Fig. 1c). In other areas, masses of leukocytic infiltration accompanied with portal vein congestions and high fibrosis were observed at the portal area (Fig. 1d). These results were also reported by other researchers [45-46]. According to Leo et al., (1982) [47] the vaculoation of the liver cells can be attributed to the swelling of mitochondria and proliferation of endoplasmic reticulum. The mechanism of Cd-mediated hepatotoxicity may involve two pathways [48] - one for the initial injury produced by the direct effects of $\mathrm{Cd}$ and the other for the subsequent injury produced by inflammation from the activation of Kupffer cells and neutrophil infiltration. Primary injury appears to be caused by the binding of $\mathrm{Cd}$ to thiol groups on critical molecules in mitochondria. The inactivation of the thiol group can cause oxidative stress, mitochondrial permeability transition, and mitochondrial dysfunction. Although Cd may injure hepatocytes directly, it is also possible that hepatocellular injury may be caused by the results of ischemia included by endothelial cell damage [49]. It was observed that liver exhibited normal structure without any histological alterations (Fig. 1e) in the quercetin-treated group.

In the $\mathrm{Cd}$ chloride and quercetin co-treated group, an improvement was recorded in the hepatic tissue. In these specimens, most hepatocytes regained their normal appearance with euchromatic nuclei and uniform cytoplasm. Also, an increase of binucleated cells was demonstrated. The central vein appeared more or less normal and the sinusoids appeared with activated kupffer cells (Fig. 1f). Few portal areas still suffered from proliferation of bile ductule (Fig. 1g). Also, a small mass of cellular infiltration was located at the central vein area (Fig. 1h). Our results are in agreement with $[13,50]$.

\section{Kidney Histopathology}

A histological analysis of the renal cortex revealed that control rats showed normal morphology with well-defined renal corpuscles (Fig. 2a).

The rats treated with $\mathrm{Cd}$ showed nephrotoxic effects of $\mathrm{Cd}$ exposure. The microscopic examination has revealed that Cd intake affected the tubules of the nephron more than the glomerular parts, where the installation of the epithelial or toxic parenchimatous tubulonephritis, expressed through the even desquamation of the epithelial cells of the renal tubules or cytoplasmic vacuolation, appeared in the cells of the tubules with interstitial congestion. Also, fragmented renal corpuscles could clearly be seen (Fig. $2 \mathrm{~b})$. In most of the cortical area we recorded atrophied glomerulus with wide urinary space (Fig. 2c). These results are in agreement with those obtained by $[12,28]$.

The histological analysis of the renal cortex revealed that the quercetin-treated group showed that the tubular cells, glomular parts, and interstitial tissue had normal morphology (Fig. 2d).

The administration of quercetin to Cd-treated rats resulted in improvement in the tubular structure where damage to the tubular cells were not observed and the glomeruli appeared normal with capsular space (Fig. 2e). A similar result was obtained by $[13,51]$. On the other hand, glomular parts exhibited minimal histologic changes (Fig. 2h).

\section{Conclusions}

This study confirmed that $\mathrm{Cd}$ exposure caused damage in the liver and the kidney as shown by alterations in studied biochemical parameters and histological changes. These adverse effects were attenuated by quercetin in the treated group. Quercetin manifested a protective effect against Cd-induced toxicity in liver and kidney, which 
might be through attenuating lipid peroxidation and the elevation of enzymatic antioxidant levels, which indicated that quercetin possesses antioxidant and hepatorenal protective properties.

\section{References}

1. KEDAM T.R., SHEIK R.B., BAI M.M., HASEENABHANU S.K. A histological study on acrylamide and Cd chloride altered chick embryonic liver. IOSR J Pharm. 2 (1), 1, 2012.

2. STOHS S.J., BAGACHI D., HASSOUN E., BAGUCHI M. Oxidative mechanisms in the toxicity of Chromium and $\mathrm{Cd}$ ions. J Environ Path Toxicol Oncol. 19, 201, 2000.

3. VELICKOV A., JANCIC N., DINIDIC N., RANCIC I., BOJANIC N., KRSTIC M. Histological and histochemical characteristics of rat myocardium in $\mathrm{Cd}$ toxicosis. Acta Medica Medianae. 52 (2), 15, 2013.

4. MICHAEL C., JORGE P. Endocrine disruption by Cd, a common environmental toxicant with paradoxical effects on reproduction. Exp Biol Med. 229 (5), 383, 2004.

5. KARA H., KARATAS F., CANATAN H., SERVI K. Effects of exogenous metallothionein on acute Cd toxicity in rats. Biol Trace Elem. Res. 104 (3), 223, 2005.

6. BRZOSKA M.M. MONIUSZKO-JAKONIUK J., PILATMARCINKIEWICZ B., SAWICKI B. Liver and kidney function and histology in rats exposed to $\mathrm{Cd}$ and ethanol. Alcohol Alcolism. 38 (1), 2, 2003.

7. KANG M.Y., CHO S.H., LIN Y.H., SEO J.C., HONG Y.C. Effects of environmental $\mathrm{Cd}$ exposure on liver function in adults. Occup Environ Med. 70, 268, 2016.

8. SOLAIMAN D., JONAH M.M., MIYAZAKI W.H.O.G., BHATLACHARYYA M.H. Increased metallothionin in mouse liver, kidneys and duodenum during lactation. Toxicol Sci. 60, 184, 2001

9. OJO O.A., AJIBOYE B.O., OYINLOYE B.E., OJO A.B., OLAREWAJU O.I. Protective effect of Irvingia gabonensis stem bark against $\mathrm{Cd}$-induced toxicity in albino rats. Advances in Pharmaceutics. Hindiwi Publishing Co-operation; Article ID 894610, 8, 2014.

10. MAHESWARI C. VENKATNARAYANAN R. Protective effect of orithosiphon stamineus leaves against lead acetate and $\mathrm{Cd}$ chloride included renal dysfunction in rats. Int Res $\mathrm{J}$ Pharm. 4 (14), 232, 2013.

11. ALBASHA M., AZAB A. Effect of $\mathrm{Cd}$ on liver and amelioration by aqueous extracts of fenugreek seeds, rosemary, and cinnamon in guinea pigs: Histological and biochemical study. Cell Biol. 2 (2), 7, 2014.

12. EL-REFAIY A.I., EISSA F.I. Histopathological and cytotoxicity as biomarkers in treated rats with $\mathrm{Cd}$ and some therapeutic agents. Saudi J Biol Sci. 20, 265, 2013.

13. RENUGADEVI J., PRABU S.M. Cd induced hepatotoxicity in rats and the protective effect of maringenin. Exp Toxicol Pathol. 62 (2), 171, 2010.

14. GALATI G., SABZEVARI O., WILSON J.X., O'BREN P.J. Prooxidant activity and cellular effects of phenoxyl radicals of dietary flavonoids and other polyphenolics. Toxicology. 177, 91, 2002.

15. PEDRIELLI P., SKIBSTED L.H. Antioxidant synergy and regeneration effects of quercetin, (-) epicatechin, and $(+)$ catechin on $\alpha$ tocopherol in homogeneous solutions of peroxidating methyl linoleate. J Agricult Food Chem. 50, 7138, 2003.

16. LUY.X., ZHANG Q., LI J., SUN Y.X., WANG L.K., CHENG W.M., HU X.Y. Antidiabetic effects of total flavonoids from
Litsea coreana leave on fat-fed, streptozotocin induced type 2 diabetic rats. Am J Chin Med. 38, 713, 2010.

17. JIN G., KAN J., ZHU Y., LEI N. Spectrophotometric determination of $\mathrm{Cd}$ (II) using the chromogenic reagent 4-(o-diazoaminophenylarsonic acid) azobenzene. Indian J Chem. 39A, 1227, 2000.

18. LOWRY O.H., ROSEBROUGH N.J., FARR A.L., RANDA R.J. Protein measurement with the Folin phenol reagent. J Biol Chem. 193 (1), 265, 1951.

19. BUEGE J.A., AUST S.D. Microsomal lipid peroxidation. Methods Enzymol. 52 (C), 1302, 1978.

20. MCCORD J.M., FRIDOVICH I. Superoxide dismutase. An enzymatic function for erythrocupein (hemocuprein). J Biol Chem. 244 (22), 64049, 1969.

21. AEBI H. Catalase estimation in methods of enzymatic analysis, H.V. Bermeye, Verlag Chemis, Ed. 673, 1974.

22. ROTRUCK J.T., POPE A.L., GANTHER H.E., SWANSON A.S., HAFEMA D.G., HOEKSTRA W.G. Selenium: biochemical role as a component of glutathione peroxidase. Science. 179 (4073), 588, 1973.

23. BANCROFT D., GAMBLE M. The theory and practice of histological technique. $5^{\text {th }}$ edition. Churchil Living Stone. 75, 2002.

24. IBIAM A.V., UGWUJA E.I., EJEOGO C., UGWU O. Cd-induced toxicity and the hepatoprotective potentials of aqueous extract of Jessiaea nervosa leaf. Advanced Pharmaceutical Bulletin. 3 (2), 309, 2013.

25. JARAMILLO-JUREZ F., RODRGUEZ-VZQUEZ M.L., RINCN-SNCHEZ A.R., CONSOLACIN MARTNEZ C.M., ORTIZ G.G., LIANAS J. Acute renal failure induced by carbon tetrachloride in rats with hepatic cirrhosis. Ann Hepatol. 7 (4), 331, 2003.

26. EL-KADY A.A., SHARAF H.A., ABOU-DONIA M.A., ABBES S., NAGUIB K., OUESTATLI R., ABDELWAHHAB M.A. Adsorption of $\mathrm{cd}^{2+}$ ions on an Egyptian montmorillonite and toxicological effects in rats. Appl Clay Sci. 44 (1-2), 59, 2009.

27. FINCO D.R. Kidney function. In: Kaneko J.J., Harvey, Bruce M.L., editors. Clinical biochemistry of domestic animal. $5^{\text {th }}$ ed. San Diego, CA: Academic Press; 462, 1997.

28. EL-MORSY A.M., SAKR S.A., BAYOMY M.F. Ameliorative effect of aqueous leaves extract of Rosmarius officinalis on $\mathrm{Cd}$ induced kidney injury in albino Rats. $\mathrm{J}$ Biosci Appl Res. 1 (1), 10, 2015.

29. EL-BOSHY M.E., RISHA E.F., ABDELHAMID F.M., MUBARAK M.S., HADDA T.B. Protective effects of selenium against $\mathrm{Cd}$ induced hematological disturbances, immunsuppressive, oxidative stress and hepatorenal damage in rats. J. Trace Elem. Med. Biol. 29, 104, 2015.

30. SUDO J., HAYASHI T., KIMUTO S., KAKUNO K., TERUI J., TAKASHIMA K., SOYAMA M. Mechanism of nephrotoxicity included by repeated administration of $\mathrm{Cd}$ chloride in rats. J Toxicol Environ Health. 48 (4), 333, 1996.

31. GIBELLINI L., PINTI M., NASI M., MONTAGNA J.P., DE BIASI S., ROAT E., BERTONCELL L., COOPER E.L., COSSARIZZA A. "Quercetin and Cancer Chemoprevention. Evid Based Complement Alternat Med. Article ID 591356, 15, 2011. doi:10.1093/ecam/neq053

32. HEIJNEN C.C.M., HAENEN G.R.M.N.M., VAN ACKER F.A.A., VANDER VIJGH W.J.F., BAST A. Flavonoids as peroxynitrite scavengers: the role of the hydroxyl groups. Toxicology in vitro. 15, 3, 2001.

33. ZEASHAN H., AMRESH G., SINGH S., RAO C.V. Hepatoprotective activity of Amaranthus spinosus in experimental animals. Food Chem Toxicol. 46 (11), 3417, 2008. 
34. EL-SHARAKY A.S., NEWAIRY A.A., BADRELDEEN M.M., EWEDA S.M., SHEWEIRA S.A. Protective role of selenium against renal toxicity induced by $\mathrm{Cd}$ in rats. Toxicology 235, 185, 2007.

35. THIJISSEN S., CUYPERS A., MARINGWA J., SMEETS K., HORMANS N. Low Cd exposure triggers a biphasic oxidative stress response in mice kidneys. Toxicology. 236, 29, 2007.

36. STOHS S.J., BAGCHI D. Oxidative mechanisms in the toxicity of metal ions. Free Radic Biol Med. 18 (2), 321, 1995.

37. OGJANOVIC B.I., PAVLOVIC S.Z., MALETIC S.D., ZIKIC R.V., STAJN A.S., RADOKICIC R.M., SOICIC Z.S., PETROVIC V.M. Protective influence of vitamin E on antioxidant defense system in the blood of rats treated with Cd. Physiol Rev. 52, 563, 2003.

38. OBAIAH J., RANI V.A. Amelioration effect of zinc and Iron supplementation on selected oxidative stress enzymes in liver and kidney of Cd-treated male albino rat. Toxicol Int. 22 (1), 1, 2015.

39. NAGARAJ M., SUMITHA S., VARALAKSHMI P. Effect of luped, apentacyclic tritepene, on lipid peroxidation and antioxidant status in rate kidney after chronic $\mathrm{Cd}$ exposure. $\mathrm{J}$ Appl Toxicol. 20, 413, 2000.

40. FILEK M., KESKINEN R., HARRIKAINEN H., AZAREJKO I., JANIAK A., MISZALSKI Z., GOLDA A. The protective role of selenium in rape seedlings subjected to Cd stress. J plant Physiol. 26; 165 (8), 1833, 2008.

41. STOHS S.J., BAGCHI D., HASSOUN E., BAGCHI M. Oxidative mechanism sin the toxicity of chromium and $\mathrm{Cd}$ ions. J Environ Pathol Toxicol Oncol 19, 201, 2000.

42. SUNAINA A., ANSARI B. Biochemical markets of oxidative stress in Zebra fish Danio ratio exposed to $\mathrm{Cd}$ chloride. Ann Biol Res. 6 (8), 6, 2015.
43. LIN W., QIANJ L.S., LONG H.E., GANG L.I., YONG W.Z. Protective effects of quercetin on Cd-induced cytotoxicity in primary cultures of rat proximal tubular cells. Biomed Environ Sci. 26 (4), 258, 2013.

44. KIM M.R., LEE J.Y., LEE H.H., ARYAL D.K., KIM Y.G., KIM S.K., WOO E.R., KANG K.W. Antioxidative effects of quercetin glycosides isolated from the flower buds of Tussilago farfare L. Food Chem Toxicol. 44, 1299, 2006.

45. TARASUB N., JUNSEECHA T., TARASUB C., AYUTTHAYA W. Protective effects of curcumin, vitamin C, or their combination on Cd-induced hepatotoxicity. J Basic Clin Pharm. 3 (2), 273, 2012.

46. SAKR S.A., BAYOMY M.F., EL-MORSY A.M. Rosemary extract ameliorates Cd-induced histological changes and oxidative damage in the liver of albino rat. J Basic Appl Zool. 71, 1, 2015.

47. LEO M.A., ARAI M., SARO M., LIEBER C.S. Hepatotoxicity of vitamin A and ethanol in the rat. Gastroenterology. 82, 194, 1982.

48. RIKANS L.E., YAMANO T. Mechanisms of Cd-mediated acute hepatotoxicity. J Biochem Mol Toxicol. 14 (2), 110, 2000.

49. LIU J., KERSHAW W., LIU Y., KLAASSEN C.D. Cdinduced hepatic endothelial cell injury in inbred strains of mice. Toxicology. 75 (1), 51, 1992.

50. ZARGAR S., SIDDIQI N.J., AL DAIHAN S.K., WANTI T.A. Protective effects of quercetin on Cd fluoride induced oxidative stress at different intervals of time in mouse liver. Acta Biochem Pol. 62 (2), 207, 2015.

51. AKTOZ T., KANTER M., HULYA U.Y., AKTAS C., ERBOGA M., ATAKAN H.I. Protective Effect of Quercetin Against Renal Toxicity Induced by Cd in Rats. Balkan Med J. 29, 56, 2012. 